\title{
Sequential sampling plan, yield loss components and economic thresholds for the pepper weevil, Anthonomus eugenii Cano (Coleoptera: Curculionidae) ${ }^{1}$
}

\author{
Alejandro E. Segarra-Carmona and Alberto Pantoja ${ }^{2}$
}

\begin{abstract}
A negative binomial distribution besł predicted pepper weevil spatial dispersion on pepper plants. Sequential sampling plans for economic threshold (EI) levels of 0.1 and 0.5 adult weevils per plant were developed and tested against a weekly schedule of sprayed and unsprayed check treatments in mini-plots. Weekly sprayed and 0.1 ET mini-plots had similar yield, but higher than 0.5 ET or mini-plots never sprayed. Direct cost to farmers was the same either with $0.1 \mathrm{EI}$ or weekly sprays. However, insecticide applications were reduced by one-third with 0.1 EI. Fruit abortion constituted the main yield-loss component in the pepper weevil-pepper system. An empirical yield-loss vs. adult weevil population density relationship was estimated. This estimate agreed with a theoretical economic injury level of 0.01 adult per plant. Recommendations on the use of prophylactic and responsive control strategies for the pepper weevil are given.
\end{abstract}

\section{RESUMEN}

Plan de muestreo, componentes de la pérdida en rendimiento y umbrales económicos del gorgojo del pimiento

La distribución binomial negativa predijo con mayor certeza que la distribución de Poisson la dispersión del picudo del pimiento entre las plantas. Dos planes de muestreo en secuencia se desarrollaron y probaron para sendos umbrales económicos, comparados contra un programa semanal de aspersión y un testigo que nunca se asperió. El umbral 0.1 adultos por planta y el programa semanal mostraron rendimientos más altos que los de 0.5 adultos por planta o el tratamiento testigo. Los gastos directos resultaron iguales en el programa semanal y en el umbral económico de 0.1 , aun cuando el número total de aspersiones de este último se redujo en un tercio. El aborto de flores y frutos constifuyó el principal componente de pérdida causado por el picudo. La relación empírica entre pérdida y densidad del picudo se estimó en concordancia con una relación térica de $\mathbf{0 . 0 1}$ adultos por planta.

'Manuscript submitted to Editorial Board 2 February 1988.

${ }^{2}$ Assistant Entomologists, Department of Crop Protection, Agricultural Experiment Station, Mayagüez Campus, University of Puerto Rico, Río Piedras, P. R. 


\section{INTRODUCTION}

Since its introduction to Puerto Rico, the pepper weevil, Anthonomus eugenii Cano, has become one of the most severe limiting factors for the production of peppers in the northwestern districts of the island (1). Little is known about its population dynamics, and at present there are no integrated pest management (IPM) programs for this important pest. In general, the development of an IPM program for the pepper weevil requires economic risk information on whether control measures will result in economic gains. This knowledge is obtained mainly through reliable pest population monitoring and estimation, with a net effect of maximizing natural control and reducing the use of pesticides (7).

The economic determinants of pest control have recently been divided into prophylactic and responsive components (12). Currently, every pest management system relies on a balance between responsive strategies (i.e., thresholds) and prophylactic strategies (e.g., schedule treatments). Choice of the proper strategy depends upon a knowledge of the advantages of each strategy under a variety of situations. At present, pepper weevil population management in Puerto Rico lacks enough information on the advantages of responsive and prophylactic strategies. Several preliminary steps need to be addressed, such as refining population estimation and damage assessments of the pepper weevil, and determining the relative merits of the IPM components. Therefore, the primary objectives of this work were to develop and test sequential samplings for the pepper weevil; to identify relevant yield-loss components; to determine yield-loss vs. population density relationships; and to test responsive and prophylactic strategies for pepper weevil control in mini-field plots as experimental arenas.

\section{MATERIALS AND METHODS}

Experiments were conducted at the Isabela Agricultural Experiment Substation from September 1985 to June 1986. Two plantings were studied during this period: the first lasted from December 1985 to March 1986, and the second from March to June 1986. A third mature planting was used for preliminary weevil distribution studies. This mature planting (1/2 acre) was a pesticide testing plot which had not been sprayed for more than 60 days before our sampling, but was otherwise well kept. Insecticides used on this plot were fenvalerate and permethrin. Plant density was 23,920 plants/hectare in all plantings. 'Cubanelle' pepper plants were spaced $46 \mathrm{~cm}$ apart within the row and $90.1 \mathrm{~cm}$ between rows.

Mathematical distribution and sequential sampling plan development

A total of 1040 plants were sampled for 21 consecutive weeks from the 'mature planting'. The number of adult weevils per plant was deter- 
mined by directly examining 50 sequentially selected plants (first sampled plant determined randomly, sampling every tenth plant thereafter). Observed distribution was compared with theoretical Poisson and negative binomial distributions $(3,7,11)$. Chi-square analyses were used to determine goodness-of-fit of distributions with the observed data. Poisson distribution probability is obtained by:

$$
p_{\mathrm{x}}=\mathrm{e}^{-\mathrm{x} * \mathrm{X}^{\mathrm{x}} / \mathrm{x} !}
$$

where, $p$ is the probability of finding $x$ number of weevils in a sample from a population of mean $X$. In contrast the negative binomial probability is obtained by:

$$
p_{x}=[(k+x-1) ! / x !(k-1) !] *\left[R^{x} / q^{k}\right]
$$

where, $q=1+p=X / k, R=p / q=X /(k+m)$. Constant ' $k$ ' from the negative binomial was obtained by iteration from a maximum likelihood estimate from the formula:

$$
z_{\mathrm{i}}=\mathrm{S}\left[\mathrm{A}_{\mathbf{x}} /\left(\mathrm{k}_{\mathrm{i}}^{\prime}+\mathrm{x}\right)\right]-\mathrm{N} \ln \left[1+\left(\mathrm{X} / \mathrm{k}_{\mathrm{i}}^{\prime}\right)\right]
$$

where, $\mathrm{A}=$ accumulated frequency in all samples containing more than $x$ weevils. Iteration was suspended when $z \rightarrow 0$.

Sequential sampling plans were developed as described in Southwood (11) and Onsanger (7). The formulae for upper and lower acceptance and rejection lines are:

$$
\begin{aligned}
& d_{0}=\Theta n+h_{0} \text { and } \\
& d_{1}=\Theta n+h_{1},
\end{aligned}
$$

where, $d=$ cumulative number of weevils, $n=$ number of collected in the sample. The slope of these lines is given by:

$$
\Theta=\mathrm{k}^{*}\left[\log \left(\mathrm{q}_{1} / \mathrm{q}_{0}\right) / \log \left(\mathrm{p}_{1} \mathrm{q}_{0} / \mathrm{p}_{0} \mathrm{q}_{1}\right]\right.
$$

These calculations serve to construct a decision-making chart for the sequential sampling plan.

\section{Testing of sequential sampling plans and empirical economic injury levels}

Three blocks, each containing one unsprayed, one weekly schedule sprayed, and two empiric economic threshold (ET) mini-plots, were established during the first and second plantings. ET mini-plots were sprayed when adult weevil counts reached acceptance lines of sequential sampling plans developed for 0.5 and 0.1 adults per plant. These levels were selected with due consideration of required effort and previously reported levels (8). Each mini-plot had an area of $47 \mathrm{~m}^{2}$ with approximately 100 plants. Fenvalerate was applied at $0.22 \mathrm{~kg} \mathrm{AI} / \mathrm{ha}$ with a low pressure ( $<30$ psi) knapsack sprayer. Population monitoring and spraying were started at first flower. The number of bored and commercial fruit was 
determined for each mini-plot. All aborted fruits $(<1 \mathrm{~cm})$ were picked and quantified biweekly. Data was analyzed with an Anova design of randomized complete blocks. The mean of all weekly adult population estimates per treatment vs. yield loss was analyzed with linear correlation.

\section{RESULTS AND DISCUSSION}

Weevil distribution and sequential sampling plan

Development of sequential sampling plans requires prior knowledge of the probability distribution of an event to occur. Under most circumstances the use of sequential sampling plans results in increased efficiency, allowing a few samples to be enough to estimate insect populations $(2,4,6,13)$. Adult pepper weevil probability distribution was best predicted by the negative binomial $\left(X^{2}=0.6264,0.5<p<0.9\right.$; fig. 1$)$. Poisson (random) distribution, on the other hand, did not adequately predict pepper weevil distribution $\left(\mathrm{X}^{2}=15.32 \mathrm{P}<0.01\right)$. Index of clumping (11), which measures the degree of aggregation of an organism, was 286.0 , indicating that weevils have a great tendency to aggregate. Further evidence of this behavior is reflected in the large number of plants on which no weevils were observed during weekly samplings (fig. 1). The reasons for this high degree of aggregation are not well understood. However, the presence of aggregation pheromones could be

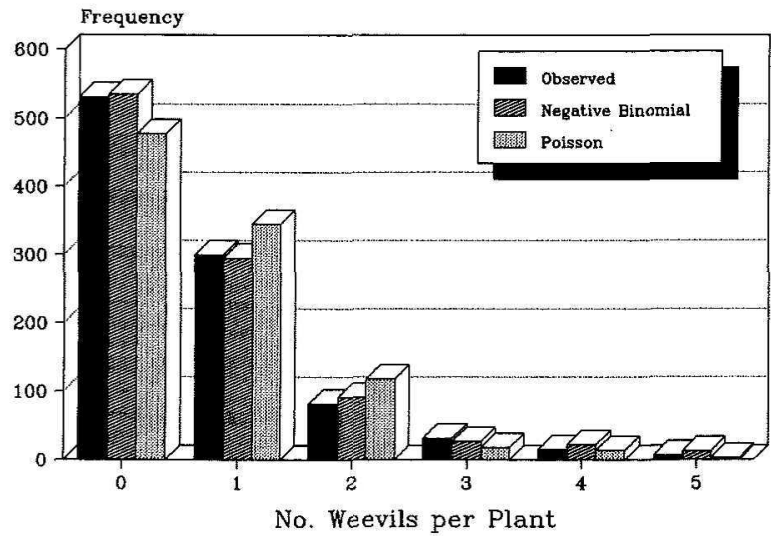

FIG. 1.-Comparison between observed pepper weevil adult distribution, Poisson and Negative Binomial distributions. 
suggested as a possible cause, given the well documented occurrence of these chemical attractants in the congener, $A$. grandis grandis Boheman, the cotton boll weevil. Negative binomial constant ' $k$ ' was found to be similar among plantings $(k=2.5)$. No relationship was found between mean weekly adult counts and $1 / k(n=21$ weeks, $r=-0.11 P>0.5)$. This lack of correlation reinforces the robustness of the calculated ' $\mathrm{k}$ ' estimates (11).

Sequential sampling plans were calculated by using $\mathrm{k}=2.5$ for ETs of 0.5 and 0.1 weevils per plant at sampling time. Rejection and acceptance lines for $\mathrm{E}^{\prime} \mathrm{T}=0.5$ were $\mathrm{H}_{0}=0.1$ and $\mathrm{H}_{1}=0.5$, respectively. For $\mathrm{ET}=0.1$ rejection and acceptance lines were $\mathrm{H}_{0}=0.01$ and $\mathrm{H}_{1}=0.1$, respectively. Sequential sampling plan equations obtained for ET 0.5 and ET 0.1 were $\mathrm{Y}_{0.5}=0.2439(\mathrm{~N}) \pm 2.012$ and, $\mathrm{Y}_{0.1}=0.0388(\mathrm{~N}) \pm 1.299$, respectively. The resulting sequential sampling plan for ET 0.1 is presented in figure 2 .

Empirical Economic Thresholds and sequential sampling plan testing

Large differences in pepper production unrelated to weevil attack were observed between plantings one and two. Second planting yields were $10 \%$ of those in the first planting (fig. 3). This sharp decrease in production was attributed to an acute viral infection in plants during the

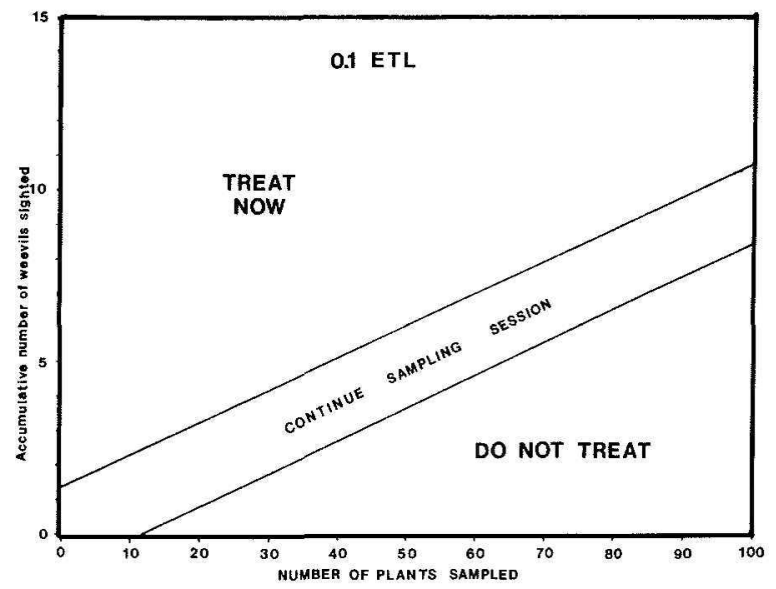

FIG. 2. Sequential sampling plan for the pepper weevil based on an economic injury level of 0.1 adults per plant. 
TOTAL NO. FRUIT PER PLANT

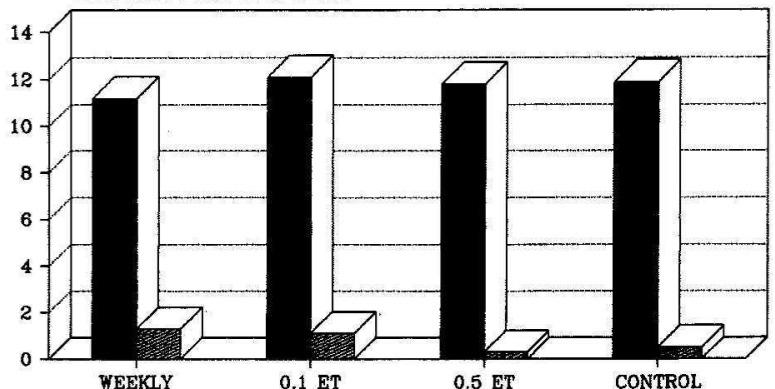

TREATMENT

FIRST 算 SECOND

FiG. 3.-Mean number of peppers produced per plant in two consecutive 'Cubanelle' pepper plantings.

second experimental planting. Losses of this magnitude are not uncommon for viral infections in peppers reported from Puerto Rico (10). Nevertheless, similar production and yield loss trends could be observed in both plantings, which serve to illustrate treatment effects and weevil attack patterns. For example, percentage relative production (i.e., number of fruit produced per treatment/total planting production * 100), showed similar patterns for both plantings, despite their total production differences (fig. 4). Weekly sprayed and $0.1 \mathrm{ET}$ mini-plots production did not significantly differ with $47.5 \pm 2.5$ and $40.6 \pm 2.4$ percent of total production, respectively. Unsprayed control and $0.5 \mathrm{ET}$ mini-plots produced significantly less with $9.6 \pm 1.3$ and $4.6 \pm 1.1$ percent, respectively (table 1). A reverse pattern was observed in percentage fruit abortion per treatment (table 1). Percentage fruit abortion follows the order of weekly schedule $\leq 0.1 \mathrm{ET}<0.5 \mathrm{ET} \leq$ unsprayed check. Attack intensity of the pepper weevil is aptly illustrated by its ability to induce up to $93 \%$ fruit loss.

Effect of treatments on economically important yield-loss components

The pepper weevil can be considered a direct pest of peppers, for it mainly attacks the harvested commodity. Under weevil attack, total yield $\left[\mathrm{Y}_{\mathrm{t}}\right]$ could be divided into three main components:

$$
\mathrm{Y}_{\mathrm{t}}=\text { Undamaged }+ \text { Bored }+ \text { Aborted. }
$$




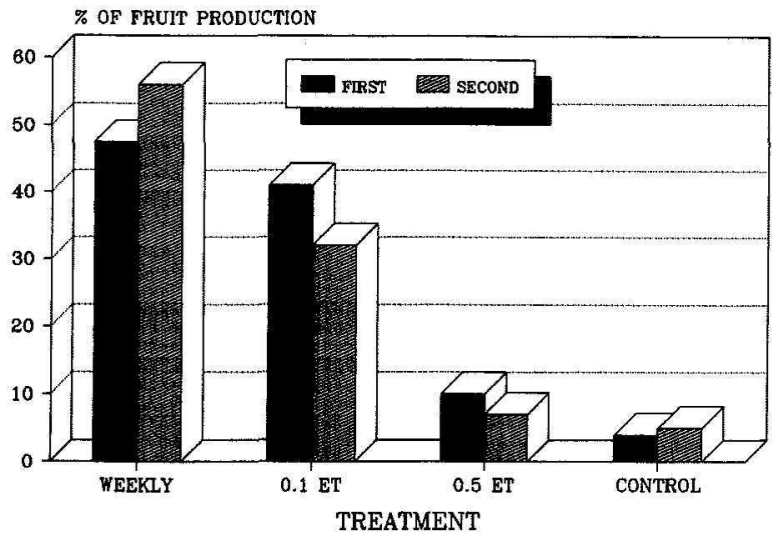

FIG. 4.-Percent of total fruit production per treatment for two consecutive 'Cubanelle' pepper plantings.

Yield loss will be given by the sum of both aborted and bored fruit (infested fruit that remains on the plant until maturity). Analysis of these components during the first planting indicated that fruit abortion is consistently the most important cause of yield loss (table 2). Yield loss components for weekly schedule and 0.1 ET mini-plots were similar, with close to $30 \%$ of total yield loss. This high yield loss, even under weekly spray schedules, indicates the devastating effect of this pest on pepper production. When $0.5 \mathrm{ET}$ production components are compared with those of the unsprayed control, the effect of intermediate insecticide

TABLE 1.Comparison of pepper yield and fruit abortion under four spray regimes from two consecutive plantings. Isabela, P. R. 1986

\begin{tabular}{lccc}
\hline Treatment & $\begin{array}{c}\text { \%of total } \\
\text { production } \\
\pm \mathrm{SE}\end{array}$ & \multicolumn{2}{c}{$\begin{array}{c}\text { Percent aborted } \\
\text { fruit per planting } \\
\pm \mathrm{SE}\end{array}$} \\
\hline Weekly & & First & Second \\
$0.1 \mathrm{ET}$ & $47.5 \pm 2.5 \mathrm{a}^{1}$ & $17.9 \pm 4.5 \mathrm{a}$ & $68.2 \pm 18.2 \mathrm{a}$ \\
$0.5 \mathrm{ET}$ & $40.6 \pm 2.4 \mathrm{a}$ & $17.3 \pm 4.5 \mathrm{a}$ & $72.6 \pm 17.6 \mathrm{a}$ \\
Control & $9.6 \pm 1.3 \mathrm{~b}$ & $47.7 \pm 3.1 \mathrm{~b}$ & $86.2 \pm 10.0 \mathrm{a}$ \\
\hline
\end{tabular}

${ }^{2}$ Means in columns followed by the same letter do not differ significantly at $\mathrm{P} \leq 0.05$. SNK procedure. 
TABLE 2.-Yield-loss component breakdown for pepper weevil attacking 'Cubanelle' peppers in Isabela $P . R .1986$

\begin{tabular}{lccc}
\hline & \multicolumn{3}{c}{ Percent $\pm \mathrm{SE}$} \\
\cline { 2 - 4 } Treatment & Undamaged fruit & Aborted & Bored \\
\hline Weekly & $69.0 \pm 3.8 \mathrm{a}^{1}$ & $17.9 \pm 4.5 \mathrm{a}$ & $13.1 \pm 1.9 \mathrm{a}$ \\
$0.1 \mathrm{ET}$ & $70.2 \pm 4.3 \mathrm{a}$ & $17.3 \pm 4.5 \mathrm{a}$ & $12.5 \pm 4.2 \mathrm{a}$ \\
$0.5 \mathrm{ET}$ & $23.8 \pm 2.9 \mathrm{~b}$ & $47.7 \pm 3.1 \mathrm{~b}$ & $28.5 \pm 4.2 \mathrm{~b}$ \\
Control & $5.4 \pm 0.7 \mathrm{c}$ & $82.1 \pm 0.6 \mathrm{c}$ & $12.5 \pm 0.6 \mathrm{a}$ \\
\hline
\end{tabular}

${ }^{3}$ Means in columns followed by the same letter do not differ significantly at $P \leq 0.05$. SNK procedure.

protection can be illustrated. The $0.5 \mathrm{ET}$ treatment received four insecticide applications during the first planting. Initial insecticide applications on 0.5 mini-plots probably protected a sizable proportion of young fruit from oviposition and subsequent abortion. These protected fruits were probably attacked at a more mature stage when susceptibility to abortion was lower; thus they were able to stay on the plant until maturity. These fruits were attacked interim when no insecticidal protection was present; thus they were lost as bored fruits instead of being aborted when young. In fact, $0.5 \mathrm{ET}$ mini-plots lost a significantly larger proportion of fruits as bored fruits than any other treatment $(28.5 \%)$. The importance of treatment timing on yield components is underseored by this result. It also illustrates the effect of prescribing no insecticidal treatment with sequential sampling plans when treatment was required to have avoided substantial loss.

Economic comparison of treatments indicated no cost difference between weekly scheduled and 0.1 ET (table 3). Whereas scouting costs contributed one-third of 0.1 ET total costs, insecticide applications were reduced by $25 \%$. Many indirect benefits can be derived from the reduction of insecticides, such as natural enemy preservation, and the reduction of personal and environmental risks. Unfortunately, the intangible nature of these benefits usually leads to their dismissal in favor of easierto-follow weekly spray schedules.

TABLE 3.-Economic comparison between four Fenvalerate application regimes from two consecutive pepper plantings

\begin{tabular}{lcccc}
\hline & No. sprays & \multicolumn{3}{c}{ Cost per acre in dollars } \\
\cline { 3 - 5 } Treatment & per planting & Materials & Sevting & Total \\
\hline Weekly & 12 & $\$ 180.00$ & $\$ 0.00$ & $\$ 180.00$ \\
$0.1 \mathrm{ET}$ & 8 & $\$ 120.00$ & $\$ 60.00$ & $\$ 180.00$ \\
$0.5 \mathrm{ET}$ & 3 & $\$ 45.00$ & $\$ 60.00$ & $\$ 105.00$ \\
Control & 0 & $\$ 0.00$ & $\$ 0.00$ & $\$ 0.00$ \\
\hline
\end{tabular}

${ }^{\prime}$ Average number of insecticide applications for each planting.

${ }^{2}$ Total cost per planting @ \$15/application/aere ( $\$ 10$ material and $\$ 5.00$ labor).

${ }^{3}$ Based on a fixed rate of $\$ 5,00 /$ acre/week. 
Pepper weevil population density-yield loss relation

Perhaps the most important relationship needed for the establishment of an IPM program is the pest density-yield loss relationship. To obtain a reasonable estimate of this relationship, the average adult weevil density (weevils/plant) for each mini-plot was plotted against its corresponding yield loss (fig 5 ). Correlation of these variables was highly significant with $r=0.94$. by the model: fruit loss $=7.685+128.63^{\circ}$ (number of adult weevils per plant). On the basis of this model, the weevil population required to inflict $10 \%$ damage would be 0.017 weevils per plant (i.e., 1.7 weevils $/ 100$ plants sampled.

A theoretical economic injury level (EIL) was calculated with the formula of Pedigo et al. (9):

$$
\mathrm{EIL}=\mathrm{C} / \mathrm{VIPK}^{3}
$$

Theoretical EIL is therefore:

$$
\begin{aligned}
\mathrm{EIL} & =484.0 /(600 \times 0.0002 \times 16.5 \times 0.9), \\
& =271.60 \text { adults } / \text { ha or, } \\
& =0.011 \text { weevils per plant }
\end{aligned}
$$

This theoretical estimate of 0.011 weevils per plant is in agreement with our earlier estimate of 0.017 weevils per plant, when the farmer allowed a $10 \%$ loss. Both EILs presented here represent population levels far lower than those observed under our 0.1 ET, or even under weekly treatments with fenvalerate. The use of an ET lower than the 0.01 EIL can not be cost-effectively implemented into a scoutingmonitoring IPM program. Even if we used 0.01 EIL as our ET, a minimum of 328 plants had to be sampled consecutively without weevils to reject the null hypothesis $\mathrm{H}(0)$. Allowing an average 2-minute sampling time per plant, a single sampling session would last more than 11 man-hours, and could represent up to a twenty-fold increase in scouting expenditures. Evidently, such expenditure increase makes unacceptable the use of responsive control programs of whole plant inspections. Therefore, special emphasis should be given to lowering scouting costs by the

Where,

$\mathrm{C}=$ Cost of management actions per hectare $=\$ 484.00 / \mathrm{ha}$;

$\mathrm{V}=$ Market value of commodity per metrie ton $=\$ 600.00 / \mathrm{m}^{\prime} \mathrm{T}$;

$I=$ Equivalents of lesion per individual weevil per hectare $=0.0002 /$ adults $/$ a. .

It is assumed that one $?$ is capable of damaging 60 peppers or $3.0 \mathrm{~kg}$ [Gordon

(5)]. Since each plant is capable of producing 13 peppers $(0.65 \mathrm{~kg})$, then a $f$ is capable of damaging the production of 4.6 plants. At 23,920 plants/ha, the proportion of plants damaged per $Q$ is $4.6 \% 23920$ or $\mathrm{I}=0.0002$;

$\mathrm{D}=$ Economic loss per unit of equivalent $=16.5 \mathrm{mT} / \mathrm{ha}$;

$K=$ Proportion of weevil poptlation reduced by management actions $=0.90$

(typieal of many insecticides). 


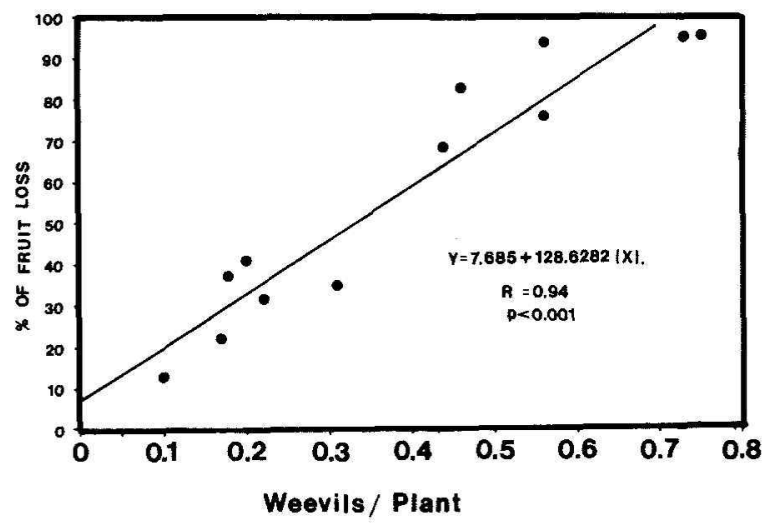

FIG. 5.-Yield loss-weevil density relationship for the pepper weevil on 'Cubanelle' peppers. Number of weevils per plant represent overall planting average.

development of effective and low cost population monitoring methods, mainly through reductions in time-units and effort.

Our analysis indicates that under the present conditions pepper weevil population management should emphasize a prophylactic approach over responsive schemes during epizootic conditions. Responsive schemes substantially reduced chemical application dependence, and could be emphasized in areas of low endemic weevil populations. Responsive management of the pepper weevil can replace or reduce prophylactic management components if scouting expenditures are lowered. In addition, integration of management techniques such as natural enemy importation, augmentation and conservation, coupled with host plant resistance, should be paramount in efforts against this important pest.

\section{LITERATURE CITED}

1. Abreu, E. and C. Cruz, 1985. The occurrence of the pepper weevil, Anthonomus eugenii Cano (Coleoptera: Curculionidae) in Puerto Rico. J. Agrie. Univ. P. R. 69: 223-24.

2. Ba-Angood, S. A. and R. K. Stewart, 1980. Occurrence, development and distribution of cereal aphids on early and late cultivars of wheat, barley and oats in Southwestern Quebec. Can. Entomol. 112; 615-20.

3. Bliss, C. I. and R. A. Fisher, 1953. Fitting the negative binomial distribution to biological data. Biometrics 9: 176-200. 
4. Foster, R. E., J. J. Tollefson and K. L. Steffey, 1982. Sequential sampling plans for adult corn rootworms (Coleoptera: Chrysomelidae). J. Econ. Entomol. 75: 791-93.

5. Gordon-Mendoza, R., 1984. Control químico y biología del picudo del pimiento, $A n-$ thonomus eugeniz Cano (Coleoptera: Curculionidae) en Puerto Rico. M. Sc. Thesis. Dep. Crop Prot., Univ. P. R., Mayagiez Campus.

6. Martel, P., J. Belcourt, D. Choquette and G. Boivin, 1986. Spatial dispersion and sequential sampling plan for the Colorado potato beetle (Coleoptera: Curculionidae). J. Econ. Entomol. 79: 414-17.

7. Onsanger, J. A., 1976. The rationale of sequential sampling, with emphasis on its use in pest management. USDA Tech, Bull, 1526 .

8. Ozaki, H. Y. and W. E. Genung, 1982. Insecticide evaluation for pepper weevil control. Proc. Fla. Hort, Soc. 95: $347-48$.

9. Pedigo, L. P., S. C. Hutchins and L. G. Higley, 1986. Eeonomic injury level in theory and practice, Ann. Rev. Entomol. 31: 341-68.

10. Pérez, J. E., H. Irizarry and A. Cortés-Monllor, 1974. Present status of virus infections of peppers in Puerto Rico. J. Agric. Univ. P. R. 58: 137-39.

11. Southwood, T. R. E., 1978. Ecological methods. Chapman and Hall, New York.

12. Vandermeer, J. and D. A. Andow, 1986. Prophylactic and responsive components of an integrated pest management program. J. Econ. Entomol. 79: 299-302.

13. Waters, W., 1955. Sequential sampling in forest insect surveys. For. Sci. 1: 68-79. 
